\title{
Effect of immigration time and beetle density on development of the cabbage stem flea beetle, (Psylliodes chrysocephala L.) and damage potential in winter oilseed rape
}

\author{
Nils Conrad ${ }^{1} \cdot$ Meike Brandes ${ }^{2} \cdot$ Bernd Ulber $^{3} \cdot$ Udo Heimbach $^{2}$ \\ Received: 30 October 2020 / Accepted: 28 April 2021 / Published online: 2 June 2021 \\ (c) The Author(s) 2021
}

\begin{abstract}
In a semi-field net cage experiment set up in three growing seasons (2015-2018) at Julius-Kühn Institute Braunschweig, Germany, the influence of different release times of adult cabbage stem flea beetles, Psylliodes chrysocephala (early September, mid-September, early October) and different beetle densities $\left(6.7,13.3\right.$ and 20 beetles $\left./ \mathrm{m}^{2}\right)$ on reproduction and damage potential in winter oil seed rape was investigated. In parallel to the cage trials, the number of deposited eggs was assessed in small boxes exposed in the field. Beetles released in early September laid significantly more eggs compared to beetles released early October, with a maximum of 270 eggs per female. The early release of beetles resulted in significantly higher numbers of larvae in autumn, but this differed significantly between the years. Warm autumn or winter conditions led to continued egg laying and development, whereas cold conditions stopped the reproduction. Significant yield losses (25\%) and significant plant losses during winter were only found in 2016/17 in treatments with an early release of high numbers of beetles $\left(20\right.$ beetles $\left./ \mathrm{m}^{2}\right)$. The German damage threshold of 3-5 larvae per plant was reached when 13 beetles $/ \mathrm{m}^{2}$ were released before 20th September and 20 beetles per $\mathrm{m}^{2}$ after 20th September. Data of this study can be used for a better damage prediction and a more targeted beetle control.
\end{abstract}

Keywords Oviposition · Larvae · Integrated pest management · Damage threshold · Yield loss

\section{Introduction}

The cabbage stem flea beetle, Psylliodes chrysocephala L. (Coleoptera: Chrysomelidae), is one of the most important autumn pests in winter oilseed rape (Brassica napus L.) (Nilsson 2002; Alford et al. 2003). The adult beetles immigrate to the fields between beginning of September and end of October (Hoßfeld 1993; Johnen and Meier 2000; Conrad 2019). The females need a maturity feeding of at least 2-3 weeks before they start to deposit their eggs into the soil (Mathiasen et al. 2015b). Under German climate conditions,

Nils Conrad

nils.conrad@syngenta.com

Syngenta Agro GmbH, Maintal, Germany

2 Julius Kühn-Institut, Institute for Plant Protection in Field Crops and Grassland, Braunschweig, Germany

3 Department of Crop Sciences, Section Agricultural Entomology, Georg August-Universität Göttingen, Göttingen, Germany the feeding damage of adult beetles is usually less important compared to the damage caused by larval feeding (Schulz and Daebeler 1984; Johnen 1997). Only in years with dry weather conditions, when plants grow very slowly, feeding damage by adults is important. The larvae start hatching at the end of October. The neonate larvae bore into the petioles and stems of the plants and feed till they pupate in the soil (Schulz 1983; Nilsson 2002). The larval damage can cause high winter losses by weakening of the plants (Godan 1951a). The time of immigration, the start of oviposition and the occurrence of first larvae depend on autumn temperatures (Mathiasen et al. 2015b; Johnen and Meier 2000; Bergermeier 1992; Bonnemaison and Jourdheuil 1954; Johnen 1997).

After the ban of neonicotinoid seed treatments in the European Union in 2013, the chemical control of P. chrysocephala only relies on synthetic pyrethroids (Baroso 2013; Heimbach and Brandes 2016; Højland et al. 2015). An inadequate application timing, and a high spraying frequency have increased the severity of resistance against pyrethroids (Højland et al. 2015; Heimbach and Brandes 2016). A 
targeted use of insecticides for control of $P$. chrysocephala and other pests is necessary (Hausmann et al. 2019; Brandes et al. 2017) to avoid further resistance development and exposure of non-target organisms.

To enhance the effectiveness of insecticide applications for control of $P$. chrysocephala and to support integrated pest management in winter oilseed rape, a better understanding of the reproduction and damage potential of the insect is necessary. In Germany, two damage thresholds for P. chrysocephala infestation are used: 50 beetles per yellow water trap caught within three weeks (Hoßfeld 1993) and 3-5 larvae per plant in late autumn (Godan 1950). These thresholds have been established decades ago and need to be re-evaluated. According to Johnen (1997), sufficiently high temperatures in September and October are essential for egg-laying and larval development of $P$. chrysocephala. In the past, early immigrating adults of $P$. chrysocephala were controlled by neonicotinoid seed treatments (Dewar 2017). Following the ban of neonicotinoid seed treatments, oilseed rape plants are no longer protected by the insecticidal effect of the active ingredient during early growing stages, thus early invading beetles have got more time for damaging.

This study aimed to mimic the effect of three different immigration dates (early September until beginning October) and beetle densities $\left(6.7,13.3,20\right.$ beetles per $\left.\mathrm{m}^{2}\right)$ on the development of larvae and the damage potential of $P$. chrysocephala.

\section{Material and methods}

The semi-field experiments were conducted in crops of winter oilseed rape in Braunschweig in Lower Saxony, Germany from 2015 to 2017. In caged plots, three different infestation levels of adult P. chrysocephala and three different immigration dates were artificially established in autumn: in early September, mid-September or end of September/early October, $6.7,13.3$, and 20 beetles per $\mathrm{m}^{2}$, respectively, were released into field cages, which were positioned in a randomized block design with five replicates per treatment (As a treatment, each beetle density/release date and the check are considered). In each block, one control net cage was installed without beetles (check).

The crop was sown on 26.08.2015, 23.08.2016, and 30.08.2017, respectively. A hybrid cultivar ('Avatar') treated with the fungicides TMTD and DMM (Thiram and Dimethomorph $4 \mathrm{~g}+10 \mathrm{~g}$ (ai)/kg seed) was used. Row width was $12 \mathrm{~cm}$, with a plant density of 55 plants $/ \mathrm{m}^{2}$ envisaged.

Net cages (net $1.5 \times 2 \mathrm{~m}, 45 \mathrm{~cm}$ high) were built-up of nets (mesh size $1.3 \times 1.3 \mathrm{~mm}$ ) with a zip opening to allow sampling (Fig. 1). The net was supported by using three flexible plastic sticks per cage, and the outer $30 \mathrm{~cm}$ of the net was covered with soil. The cages were established before emergence of the crop, after application of the herbicide Butisan Gold (2.5 1/ha) (Metazachlor, Dimethenamid and Quinmerac $(500+250+500 \mathrm{~g}(\mathrm{ai}) / \mathrm{ha})$. The net cages were removed in spring at stem elongation of the plants to allow further crop development. For maintenance of the crop until harvest, infestation by spring pests was monitored using yellow water traps. When the damage threshold for stem weevils (Ceutorhynchus pallidactylus (Mrsh.), Ceutorhynchus napi Gyll.) and pollen beetle (Brassicogethes aeneus (F.)) was exceeded, insecticides were only applied around/outside the plots to reduce the pest pressure and avoid a high infestation of the plots.

The adult cabbage stem flea beetles needed for the experiments for release into net cages each year were collected from winter oilseed rape fields near Braunschweig during the $1^{\text {st }}$ week of July, right after their emergence, by using a converted leaf blower (Fa. Stihl). For aestivation, the beetles were kept in net cages $(60 \times 60 \times 60 \mathrm{~cm})(\mathrm{Fa}$. BugDorm) equipped with a potted winter oilseed plant, a pile of peat

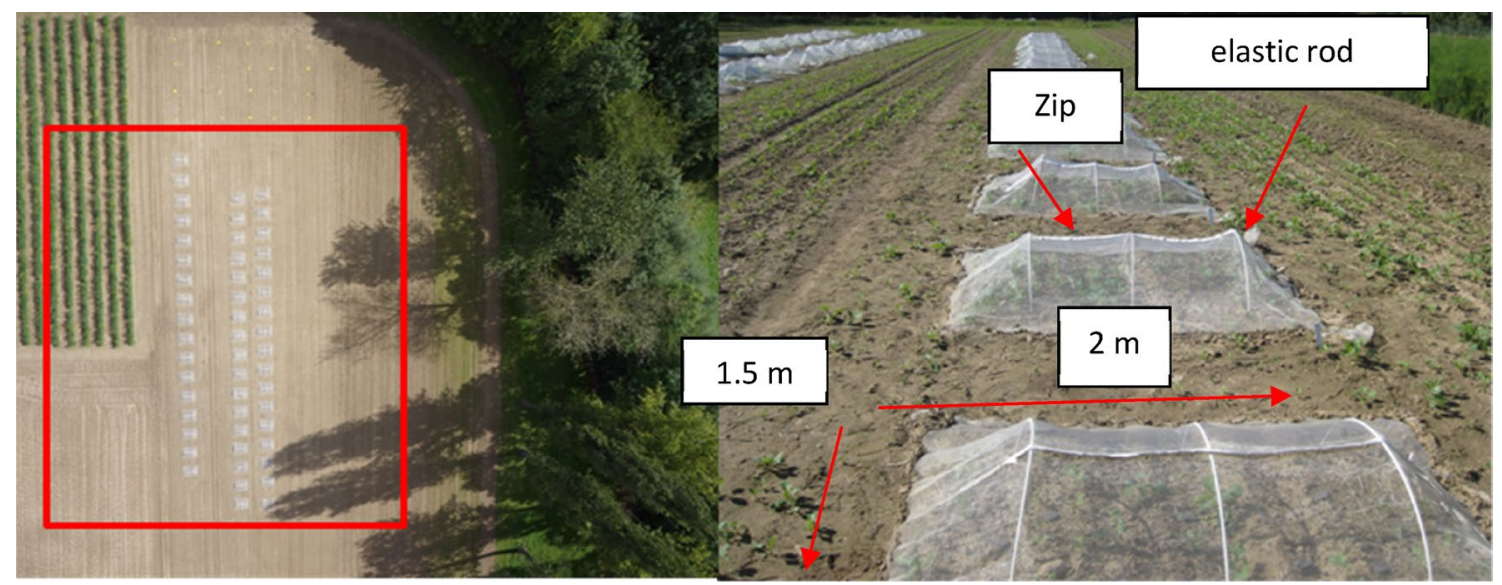

Fig. 1 Left: Aerial picture of trial site at Braunschweig, Germany. Right: Net cages on the field site 
and empty plastic pots as shelter according to Schulz (1983). These net cages were placed at a shady place in a forest. If necessary, the peat was moistened with water. At the end of July, when the beetles reduce their activity, the cages were transferred into climate chambers at $12-15^{\circ} \mathrm{C}$ and a photoperiod of 14: 10 (L: D) to slow down the activity. The beetles were subdivided into three different groups for the three releasing periods. 14 days before release into field cages, each group was exposed to $12{ }^{\circ} \mathrm{C}$ and a photoperiod of 12 : 12 (L: D) to stimulate oviposition.

One day before release of beetles, the sex was determined based on the tarsal morphology described by Kaufmann (1941) and beetles were sorted in groups of 20, 40 and 60 beetles per cage (sex ratio 1: 1). Release dates are presented in Tab 1.

The number of emerged plants per net cage was counted at the end of September and end of March in each season (2015/16: [23.09.15] BBCH 13 \& [24.03.16] BBCH 51; 2016/17: [21.09.16] BBCH 13-14 and [24.03.17] BBCH 33; 2017/18: [23.09.17] BBCH 14 and [21.03.18] BBCH $33)$. The difference between plant numbers in autumn and spring was used for calculation of winter losses, considering the destructive sampling of 10 plants per $\mathrm{m}^{2}$ in all cages for larval assessments.

Feeding damage by adult beetles was assessed at three occasions in September. The percentage of damaged leaf area was visually estimated on 30 plants per cage.

The number of $P$. chrysocephala larvae per plant was counted at three different dates (end of November, January, and end of March) by destructive sampling of ten plants from each cage. Plants were stored at $3{ }^{\circ} \mathrm{C}$ without light until dissection in the laboratory. Maximal storage time was 7 days. Shoots and petioles of each plant were dissected under a binocular using a scalpel and the number of larvae was counted.

At harvest time, all plants of each cage were sampled and threshed separately. All seed samples had the same moisture when the weight was measured.

In parallel with the net cage experiments, the oviposition activity of the beetles was determined in 2016/17 and 2017/18.

Table 1 Release dates of adult Psylliodes chrysocephala and $\mathrm{BBCH}$ growth stage of winter oilseed rape in 2015/16-2017/18 in net cage trials at Braunschweig, Germany

\begin{tabular}{llll}
\hline \multirow{2}{*}{ Date } & \multicolumn{2}{l}{ Release date } & \\
\cline { 2 - 4 } & 2015 & 2016 & 2017 \\
\hline Early & BBCH 11-12 & BBCH 10-12 & BBCH 11 \\
& $(11.09 .15)$ & $(05.09 .16)$ & $(08.09 .17)$ \\
Mid & BBCH 13 & BBCH 13 & BBCH 13-14 \\
& $(21.09 .15)$ & $(19.09 .16)$ & $(22.09 .17)$ \\
Late & BBCH 14-15 & BBCH 14-16 & BBCH 14 \\
& $(30.09 .15)$ & $(04.10 .16)$ & $(05.10 .17)$ \\
\hline
\end{tabular}

Seven and ten Bellaplast plastic boxes $(17.0 \times 12.1 \times 6.4 \mathrm{~cm})$, respectively, were set up in the area of the cage trial at each of the three beetle releasing dates. Each box was supplied with one pair of aestivated cabbage stem flea beetles, moist filter paper and one leaf of winter oilseed rape as food. The boxes were closed with a clear plastic lid. They were placed next to the net cages and sunk into the soil that only the top was visible. During wintertime they were covered with branches of spruce to simulate the natural cover by oilseed rape canopy. The number of deposited eggs (mainly on the moist filter paper) was checked weekly and food was renewed if necessary.

Weather conditions were recorded around $200 \mathrm{~m}$ next to the field site and expressed in temperature sums $\left({ }^{\circ} \mathrm{Cd}\right)(2 \mathrm{~m}$ height).

\section{Statistics}

The statistical software R (2015) was used to evaluate the data (The R Development Core Team 2015). For the data evaluation of the semi-field net cage trials, an appropriate statistical mixed model (package lme () (Laird and Ware 1982)) was defined for metric data and a generalized mixed model (package glmmpql ()) (Schall 1991) for count data. The data were assumed to follow a normal distribution and to be homo/heteroscedastic. These assumptions are based on a graphical residual analysis. The full statistical model included the beetle density $(6.7,13.3,20)$, the releasing date (Early, Mid, Late) and the year (2015/16, 2016/17, 2017/18), as well as all their interaction terms (two-fold and three-fold) as fixed effects. Blocks and the plots, nested in blocks were regarded as random factors. The optimal model was chosen by backward elimination of the full model with the help of the Akaike information criterion (AIC) (Zuur et al. 2009). An analysis of variance (ANOVA) was conducted, followed by a multiple contrast tests using the package multcomp. Estimated marginal means and post hoc tests for pairwise comparisons at an alpha level of 0.05 with $p$ value adjustment by the Tukey method were executed. The correlation and coefficient of determination $\left(R^{2}\right)$ between the number of larvae/plant and the number of larvae $/ \mathrm{m}^{2}$ were calculated using MS Excel 2018.

The data of the oviposition trials were analyzed by a linear model including the cumulative sum of eggs per female as target variable and the release date as explanatory variable. Before, data were checked for normal distribution and homo/heteroscedasticity.

\section{Results}

The weather conditions differed widely between years. In $2015 / 16$, the temperature in autumn was low, but the winter conditions were mild compared to the following years 
(Table 2). The highest accumulated temperature sum was in September 2016/17.

The level of damaged leaf area was generally low and never exceeded an average of $10 \%$; there was no difference between treatments.

In 2015/16 and 2016/17, oviposition was rare before onset of October and the peak of egg deposition was found during October (Fig. 2). During winter (Dec-Feb), oviposition was on a very low level, but increased again in spring, with lower numbers of eggs compared to autumn. Beetles released in early September laid clearly more eggs than beetles released in early October, but the total number of eggs laid was not significantly different between release dates; this was due to the very heterogenic fecundity (Fig. 3). The differences caused by different release dates were larger in 2016/17 (97 eggs/female when released early September and 44 early October) compared to 2017/18 (118 eggs/female early September and 97 early October). The highest number of eggs for an individual female was 270. Egg laying was observed until May-June in both years.

The number of larvae increased in all treatments between the sampling dates in November and January (Fig. 4, 5 and 6). Especially in 2015/16, an increase in larval abundance during the winter was remarkable. On the first sampling date in 2016/17, the number of larvae was higher than in 2015/16. The early release of beetles led to more larvae in all years in comparison with later released beetles.

The German damage threshold of 4 larvae per plant was only exceeded in treatments with 13.3 or 20 beetles per $\mathrm{m}^{2}$ when released at the1st and 2 nd date (until mid-September). Later released beetles only reached the larval threshold in treatments with a density 20 beetles $/ \mathrm{m}^{2}$.

When released in early September one female lead in total to $22.0( \pm 1.7 \mathrm{SE})$ and $25.1( \pm 1.7 \mathrm{SE})$ larvae at $1 \mathrm{st}$

Table 2 Temperature sums $\left({ }^{\circ} \mathrm{Cd}\right)$ (2 m hight) in September-April at the trial site Braunschweig, Germany 2015/16, 2016/17 and 2017/18. (For detailed wheater data see Conrad (2019))

\begin{tabular}{rllllrrrr}
\hline & Sept & Oct & Nov & Dec & Jan & Feb & Mar & Apr \\
\hline $2015 / 16$ & 388.6 & 266.6 & 257.1 & 254.1 & 88.7 & 110.2 & 151.1 & 259.0 \\
$2016 / 17$ & 540.8 & 287.3 & 137.7 & 118.7 & 26.7 & 106.0 & 257.4 \\
$2017 / 18$ & 409.1 & 377.2 & 180.6 & 133.7 & 125.4 & 14.2 & 118.9 & 394.9 \\
\hline
\end{tabular}

Fig. 2 a 2016/17 Egg deposition of Psylliodes chrysocephala (eggs/female $+\mathrm{SE}$ ) in boxes exposed at three release dates (black 05.09., grey, 19.09; light grey 04.10) each 7 replicates, Braunschweig, Germany. b 2017/18 Egg deposition (eggs/ female + SE) in boxes exposed at three release dates (black 08.09..; grey, 22.09.; light grey 05.10 . each 10 replicates, Braunschweig, Germany
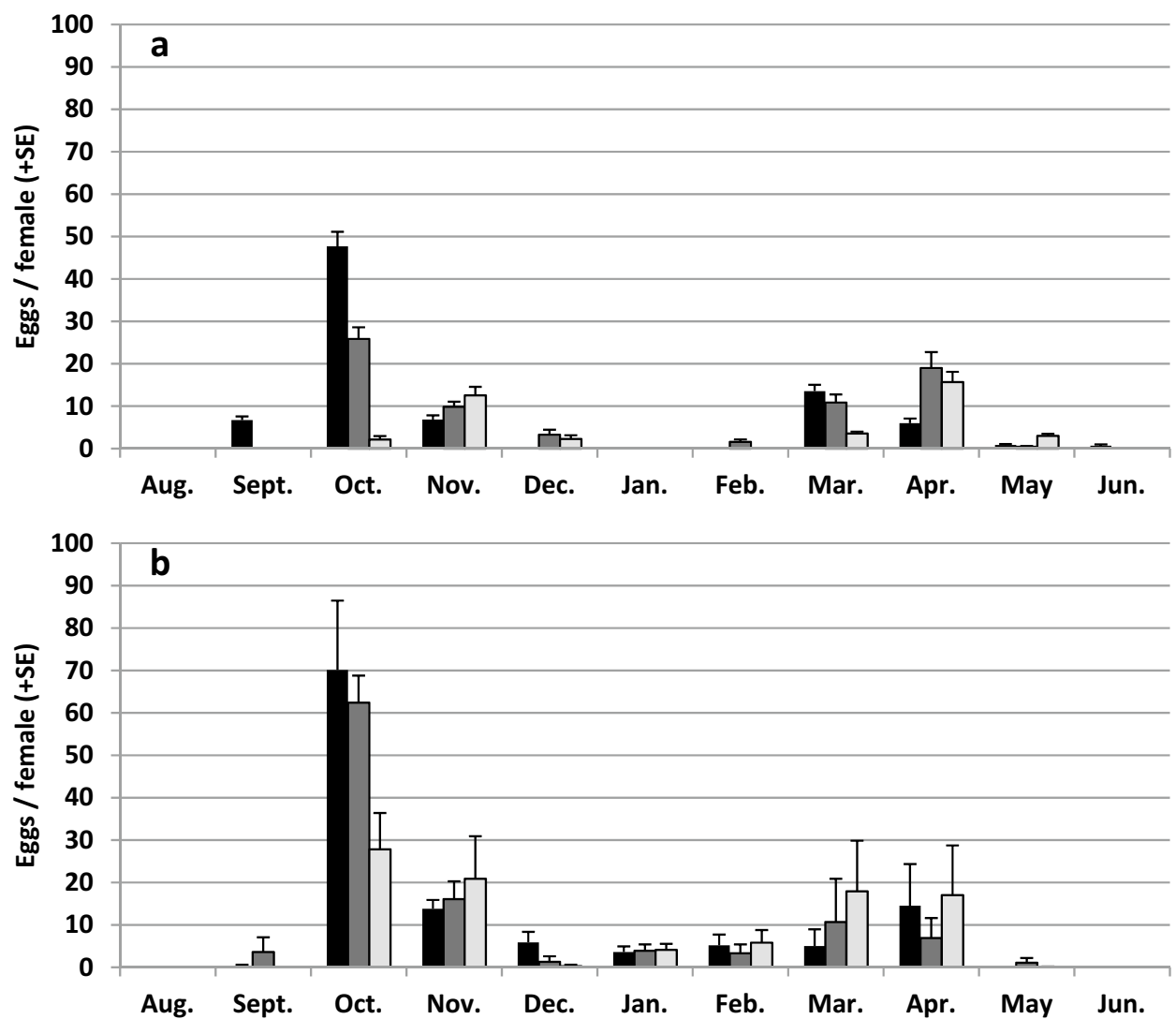


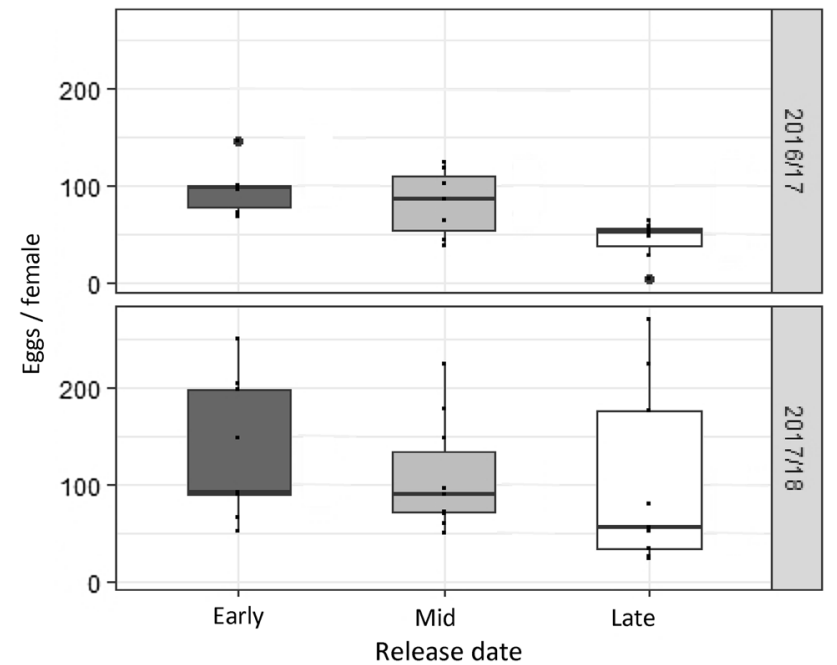

Fig. 3 Jittert Boxplot (percentiles 25 and 75\%) of total number of deposited Psylliodes chrysocephala eggs/female at different release dates (Early, Mid, Late) in boxes exposed in the field cage trial in 2016/17 and 2017/18 at Braunschweig, Germany

and 3rd sampling date in the average of the 3 years. When released mid of September $11.6( \pm 2.8 \mathrm{SE})$ and $19.8( \pm 2.1$ $\mathrm{SE})$ larvae and at release in early October $1.9( \pm 0.2 \mathrm{SE})$ and $13.0( \pm 3.0 \mathrm{SE})$ larvae in total.

For the 1st and 3rd assessment date, calculated number of larvae per $\mathrm{m}^{2}$ showed almost the same tendency as the number of larvae per plant (for the 2 nd assessment date, this calculation was not possible because a plant count was not carried out).

The increase in larvae/plant between different beetle densities was almost linear $(p=0.015)$ (Fig. 7). The graph only shows the 2nd assessment date because the number of larvae before onset of the winter is crucially for the damage potential of this pest.

Plant density was almost equal in autumn in all years and ranged between 29 and 39 plants. No significant plant losses compared to the check were assessed. Significant plant losses during winter only occurred in 2016/17 and 2017/18 in treatments with early (early release date) and high beetle infestation ( 20 and 13 beetles $/ \mathrm{m}^{2}$ ), whereas in 2015/16 no winter losses were found (Fig. 8). Significant winter losses in $2017 / 18$ were up to $27.1 \%$, which were $10 \%$ higher compared to the same treatment in the previous year.

In 2015/16, yields (Table 3 ) did not differ significantly between treatments, while in 2016/17 and 2017/18 the early release of high beetle numbers caused a significant yield reduction. The highest yield reduction was assessed in 2016/17 (25.4\%).

\section{Discussion}

Following the ban of the neonicotinoid seed treatment in the European Union in 2013, emerging crops of oilseed rape are no longer protected against the early infestation of insect pests by the residual effects of these insecticides. As a result, early immigrating adult beetles of Psylliodes

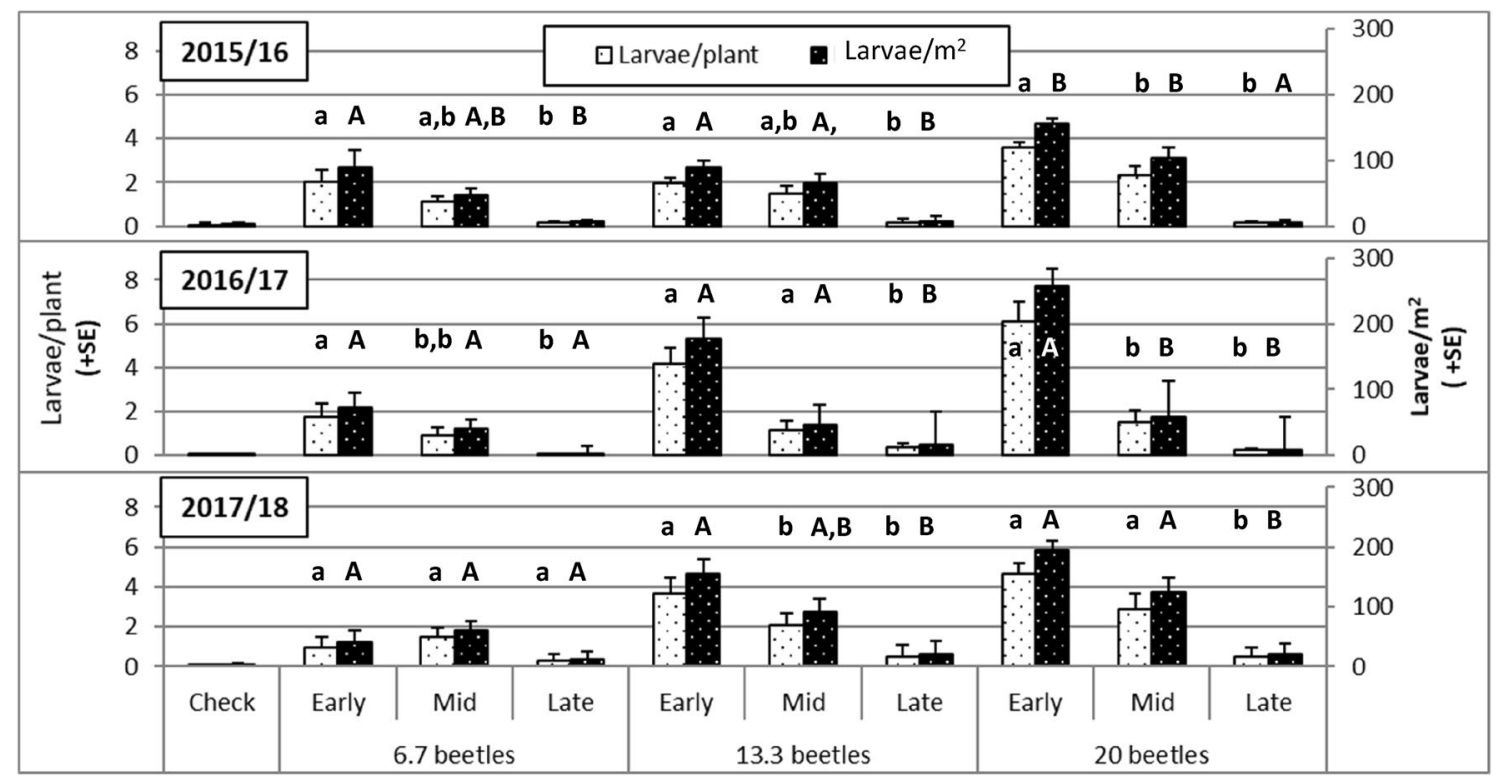

Fig. 4 Number of Psylliodes chrysocephala larvae/plant and lar$\mathrm{vae} / \mathrm{m}^{2}( \pm \mathrm{SE})$ at $1 \mathrm{st}$ assessment date: $(07.12 .2015$; $\mathrm{BBCH} 17-19$, 28.11.2016; BBCH 15-18 and 04.12.2017; BBCH 16-17) in a net cage trial at Braunschweig, Germany in 2015/16-2017/18: ANOVA, Tukey test $(p \leq 0.05)$ different letters indicate significant differences at three release dates per beetle density 


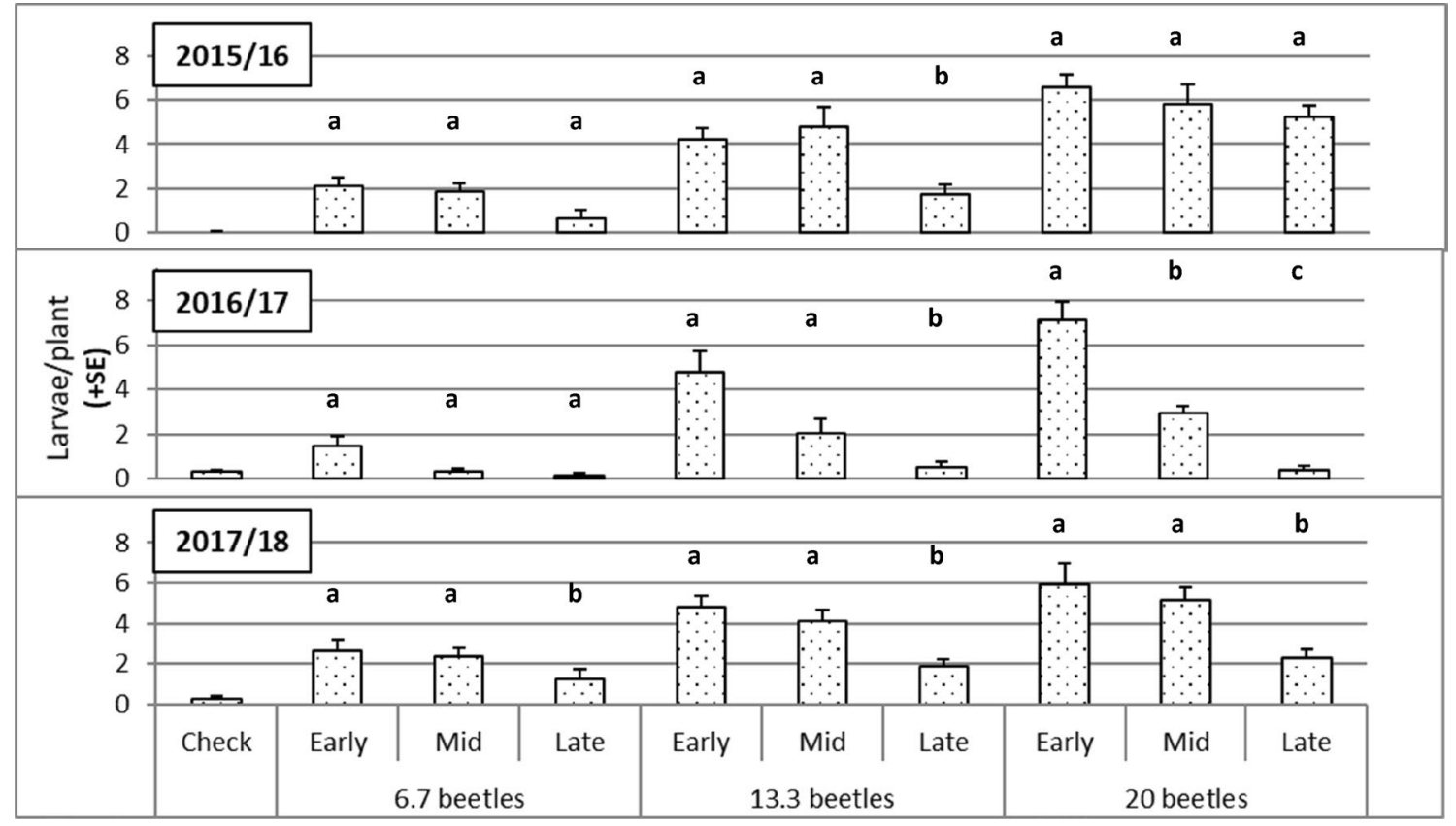

Fig. 5 Number of Psylliodes chrysocephala larvae/plant $( \pm \mathrm{SE})$ at 2nd assessment date (12.01.2016; BBCH 19, 12.01.2017 BBCH 17-19 and 15.01.2018; BBCH 19) in a net cage trial at Braunsch- weig, Germany in 2015/16-2017/18: ANOVA, Tukey test $(p \leq 0.05)$ different letters indicate significant differences at three release dates per beetle density

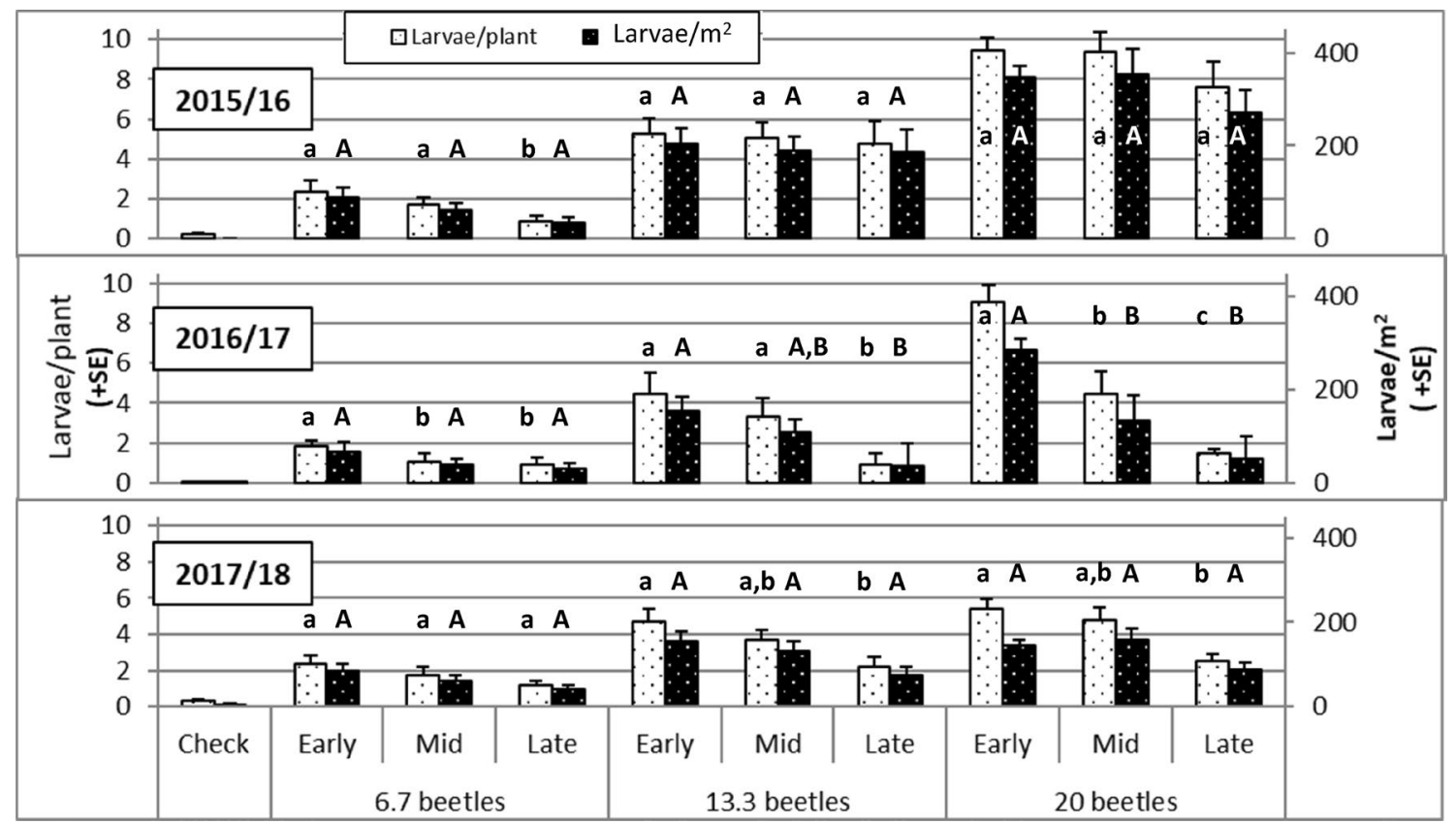

Fig. 6 Number of Psylliodes chrysocephala larvae/plant and larvae $\mathrm{per} / \mathrm{m}^{2}( \pm \mathrm{SE})$ at $3 \mathrm{rd}$ assessment date $(24.03 .2016$; BBCH 51, 17.03.2017; BBCH 31-33 and 21.03.2018; BBCH 30) in a net cage

chrysocephala are not controlled by the insecticidal seed treatments and can start feeding and depositing eggs earlier, leading to higher numbers of eggs and larvae and trial at Braunschweig, Germany in 2015/16-2017/18: ANOVA, Tukey test $(p \leq 0.05)$ different letters indicate significant differences at three release dates per beetle density

higher damage potential. Timing of crop invasion by adults is also favored by warm and dry weather conditions. The aim of this study was to evaluate the influence of earlier 


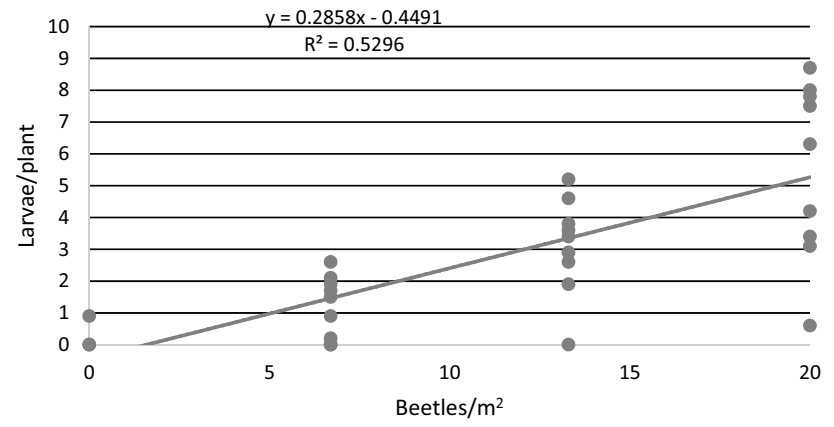

Fig. 7 Relation between beetle density $/ \mathrm{m}^{2}$ and larvae per plant over all years before onset of the winter (2nd assessment date) in the three year experiment 2015-2018 at Braunschweig, Germany

or later immigration of adults into the field, which may be caused by different weather or the lack of insecticidal seed treatment, biology and damage potential of $P$. chrysocephala.

The semi-field experiments demonstrated a major impact of the immigration time of adult cabbage stem flea beetles into the oilseed rape crop on the development of eggs and larvae and the level of plant infestation by this pest. The start of crop colonization was simulated by different dates of release of beetles into net cages in oilseed rape plots. The results indicate that the development of $P$. chrysocephala in autumn is strongly depending on ambient temperatures, which was shown by the different releasing dates and the associated temperature sums. Effects of ambient temperatures on $P$. chrysocephala have also been reported by Schulz (1983), Johnen (2009) and Mathiasen et al. (2015b).

The results of these semi-field experiments were confirmed by results of a corresponding field experiments which were carried out during the same years in open field conditions near the trial area. These trials were conducted within the same project and targeted to answer the same questions (for more information see Conrad 2019). These open field insecticide efficacy trials and similar net cage trials showed that the results of the net cage experiments are applicable also for open field conditions, although it can be assumed that there are small deviations from the open field conditions caused by a different microclimate within the net cages.

According to Johnen and Meier (2000), the beginning and period of peak oviposition is important for subsequent plant infestation by $P$. chrysocephalla. In our experiments, egg deposition by early released females started earlier compared to beetles released in October. However, even at early release dates the main egg-laying period did not start before end of September. This was shown for the first time in our experiments. Taking into account a beginning of oviposition in October, the temperature sum of $200^{\circ} \mathrm{Cd}$ (calculated using a base temperature of $4{ }^{\circ} \mathrm{C}$ (Johnen and Meier (2000)) required for the embryonic development of eggs in October and November was reached in most years not before end of October/beginning of November. The egg laying decreased strongly during wintertime (December to end of February). Considering this, the temperature regime from immigration

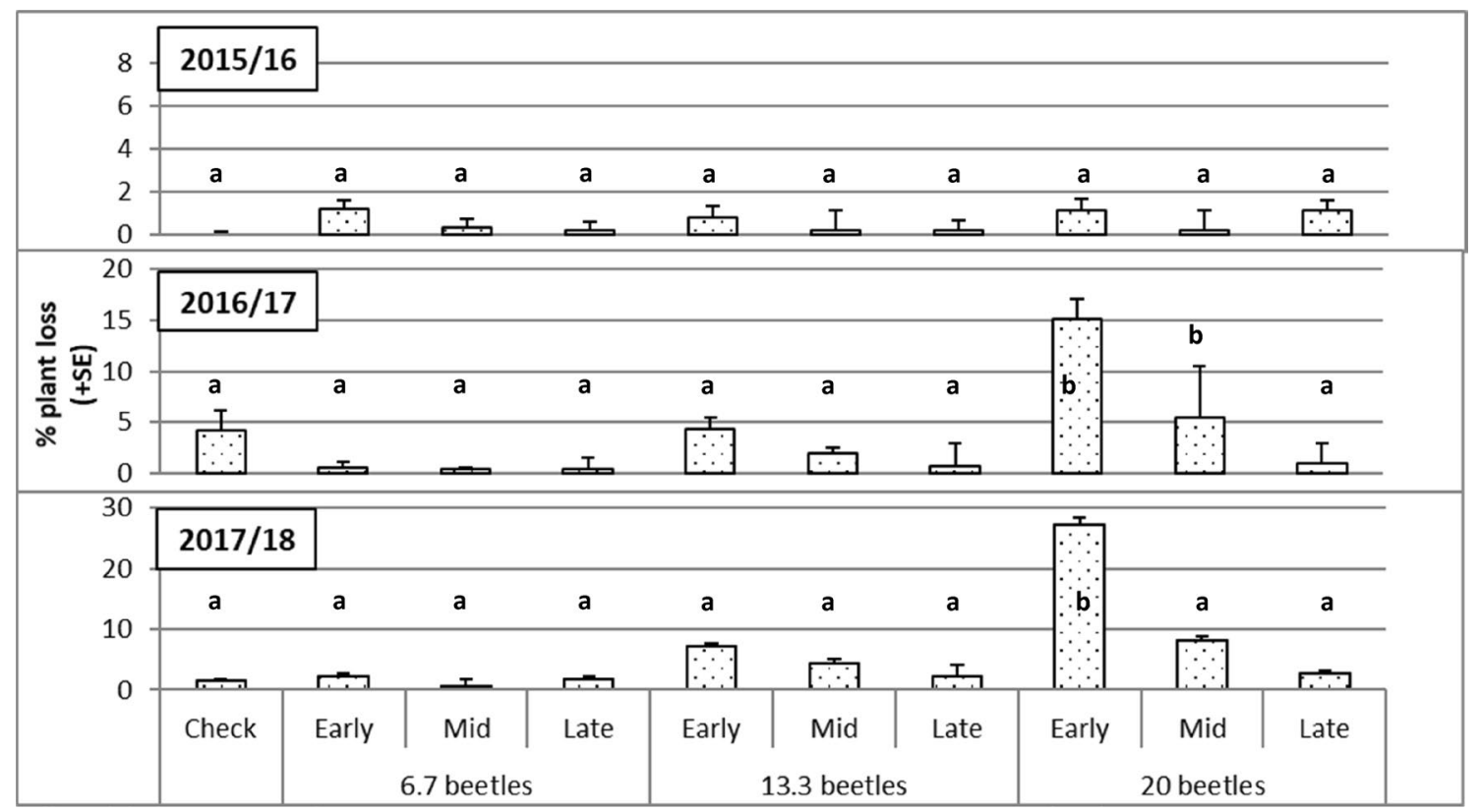

Fig. 8 Plant losses during winter (\%) in net cage trials at Braunschweig, Germany in 2015/16-2017/18. (Different letters indicate significant differences between all treatemnts per year; ANOVA, Tukey test $(p \leq 0.05))$ 
Table 3 Yield (kg/ha) in net cage trials at Braunschweig, Germany in 2015/16-2017/18. (Different letters indicate significant differences between all treatments for each year. ANOVA, Tukey test $(p \leq 0,05))$

\begin{tabular}{|c|c|c|c|c|c|}
\hline & $\begin{array}{l}\text { Beetle density } \\
\text { per } \mathrm{m}^{2}\end{array}$ & Release date & Yield $(\mathrm{kg} / \mathrm{ha})( \pm \mathrm{SE})$ & Difference & $\begin{array}{l}\text { Difference } \\
\text { to check } \\
(\%)\end{array}$ \\
\hline \multirow[t]{10}{*}{$2015 / 16$} & Check & & $3174.0 \pm 27.1$ & $\mathrm{a}$ & \\
\hline & 6.7 & Early & $3037.3 \pm 58.5$ & $\mathrm{a}$ & -4.3 \\
\hline & & Mid & $3212.7 \pm 21.5$ & $\mathrm{a}$ & 1.2 \\
\hline & & Late & 3128.7 \pm 90.7 & $\mathrm{a}$ & -1.4 \\
\hline & 13.3 & Early & $3077.3 \pm 57.1$ & $\mathrm{a}$ & 0 \\
\hline & & Mid & $\mathbf{3 2 9 4 . 7} \pm 38.2$ & a & 3.8 \\
\hline & & Late & 3233.3 \pm 72.6 & $\mathrm{a}$ & 1.9 \\
\hline & 20 & Early & $2970.7 \pm 31.5$ & $\mathrm{a}$ & -6.4 \\
\hline & & Mid & $2968.0 \pm 297$ & $\mathrm{a}$ & -6.5 \\
\hline & & Late & 3116.7 \pm 72.1 & $\mathrm{a}$ & -1.8 \\
\hline \multirow[t]{10}{*}{$2016 / 17$} & Check & & $3787.0 \pm 86.8$ & $\mathrm{a}$ & \\
\hline & 6.7 & Early & $\mathbf{3 8 6 4 . 7} \pm 18.6$ & $\mathrm{a}$ & 2.1 \\
\hline & & Mid & $3730.9 \pm 82.9$ & a & -1.5 \\
\hline & & Late & $\mathbf{3 6 5 7 . 2} \pm 137$ & $\mathrm{a}$ & -3.4 \\
\hline & 13.3 & Early & 3356.4 \pm 05.6 & $\mathrm{~b}$ & -11.4 \\
\hline & & Mid & $3833.9 \pm 28.4$ & $\mathrm{a}$ & 1.2 \\
\hline & & Late & $3930.9 \pm 29.6$ & $\mathrm{a}$ & 3.8 \\
\hline & 20 & Early & $2825.6 \pm 26.5$ & $\mathrm{~b}$ & -25.4 \\
\hline & & Mid & $3566.5 \pm 07.7$ & $\mathrm{a}$ & -5.8 \\
\hline & & Late & $\mathbf{3 8 6 2 . 3} \pm 81.9$ & $\mathrm{a}$ & 2 \\
\hline \multirow[t]{10}{*}{$2017 / 18$} & Check & & $3298.7 \pm 62.9$ & $\mathrm{a}$ & \\
\hline & 6.7 & Early & $3272.6 \pm 64.5$ & $\mathrm{a}$ & -0.8 \\
\hline & & Mid & 3275.7 \pm 98.3 & $\mathrm{a}$ & -0.7 \\
\hline & & Late & $3258.1 \pm 24.5$ & $\mathrm{a}$ & -1.2 \\
\hline & 13.3 & Early & $3059.5 \pm 71.4$ & $\mathrm{a}$ & -7.3 \\
\hline & & Mid & 3246.1 \pm 29.3 & $\mathrm{a}$ & -1.6 \\
\hline & & Late & $\mathbf{3 4 2 5 . 5} \pm 04.0$ & $\mathrm{a}$ & 3.8 \\
\hline & 20 & Early & $\mathbf{2 9 2 2 . 4} \pm 34.3$ & $\mathrm{a}$ & -11.4 \\
\hline & & Mid & $2919.3 \pm 74.5$ & $\mathrm{a}$ & -11.5 \\
\hline & & Late & $3348.3 \pm 74.1$ & $\mathrm{a}$ & 1.5 \\
\hline
\end{tabular}

until beginning of December is a key factor for the damage potential of $P$. chrysocephala. Consequently, regions with mild autumn conditions (e.g. Northern Germany or UK) are at higher risk for crop damage caused by $P$. chrysocephala. On the other hand, plant compensation for damage by adult and larval feeding is higher in regions with mild winter conditions (Godan 1950).

Mild autumn conditions in combination with a warm winter allowed females to lay eggs until May/June. This leads to a high reproduction rate with abundant offspring, whereas very low temperatures in winter cause a high mortality of adults as well as larvae, resulting in few offspring per female (Godan 1948, 1951b). In our experiments, winter conditions were not sufficiently hard to kill larvae or adults in contrast to findings of Godan (1948). It can be concluded that autumn and winter conditions can be used to predict years with low or high risk of cabbage stem flea beetle infestation in future.
This was also suggested by Mathiasen et al. (2015a), Johnen and Meier (2000) and Schulz (1983).

Different temperature regimes in the three years of study showed clear effects on the abundance of larvae, which was linked to the respective temperature sums. At higher temperatures in the year 2015/16, both the higher number of larvae per plant and the advanced larval instars before winter resulted in an increased risk of plant damage (for detailed larval age structure see Conrad 2019). Larvae of the 2nd and 3rd instar tend to consume more plant tissue compared to the 1st instar larvae, resulting in a higher damage potential. If the larval tunnelling within petioles and stems is severe, frost temperatures during winter can cause abundant freezing-off of leaves, which forces the larvae to move into the vegetation point where they find better shelter (Godan 1948, 1951b). This can lead to increased plant mortality as found in $2015 / 16$ and $2016 / 17$. 
In integrated pest management systems, the application of damage thresholds is indispensable (Nilsson et al. 2015; Hoßfeld 1993). For cabbage stem flea beetle, a threshold based on the number of adult beetles per $\mathrm{m}^{2}$ might be used to avoid critical infestation levels of more than 4 larvae per plant before winter. In commercial crops of oilseed rape, Conrad (2019) found a high correlation between the beetle density per $\mathrm{m}^{2}$ and yellow water trap catches $(r=82 \%)$ but this was not significant. Our experiments have shown, that up to a density of 13 beetles $/ \mathrm{m}^{2}$ no insecticide treatment is required if adult immigration started before the 20th of September. A treatment would have been only necessary, when more than 13 beetles $/ \mathrm{m}^{2}$ were present in the field. If immigration started after the 20th September, the threshold would go up to 20 beetles $/ \mathrm{m}^{2}$. A correlation between yellow water trap catches and larval density was shown by Green (2008) and Conrad (2019). These findings can be used for a more targeted insecticide application and control of adult $P$. chrysocephala, to avoid larval damage. Conrad et al. (2018) have demonstrated in three year field trials, that spraying of a pyrethroid insecticide (Karate Zeon, active ingredient lambda-Cyhalothrin) in early October, following the main immigration and before the main egg-laying period, significantly reduced the number of larvae. This was also found in field trial at Braunschweig by Büchs (1992). Under climatic conditions in Northern Germany, insecticide applications for control of leaf damage by adult feeding are usually only necessary under unfavorable growing conditions, with delayed emergence (e.g. under dry conditions) and low plant density (Godan, 1948, 1951b). In all three years of this study, the level of leaf feeding damage by adult flea beetles was very low in the net cages as well as in the surrounding oilseed rape fields (Conrad 2019). This supports the finding of this study that only one late insecticide treatment which is targeted to control the adults and indirectly also the number of eggs and larvae, usually provides sufficient control of cabbage stem flea beetle.

In Germany, a threshold of 3-5 larvae per plant is recommended for the larval infestation of P. chrysocephala (Godan 1950; Schulz 1983). This is in line with findings of the present study. In our experiments in the year 2015/16, a larval density of 4 larvae per plant already caused a decrease in seed yield of about $5 \%$ (not significant) when the following winter was cold. As a sound prediction of the temperatures in the following winter in autumn is not possible, insecticide treatments to control larval damage by $P$. chrysocephala must be done proactive. This study provided evidence that the damage threshold established in the past still fits for today's growing system.

This study has clearly demonstrated that the cabbage stem flea beetle is a serious pest of oilseed rape, which can cause significant yield losses. We found that the level of yield loss is highly correlated with the hardiness of the winter and the immigration time of adults in autumn. High larval numbers resulting from early and high levels of beetle infestation followed by cold winter conditions may lead to plant and yield losses, whereas a high larval infestation followed by mild winter conditions does not inevitable lead to yield losses (see trial of year 2015/16). Our results show that the ban of the neonicotinoid seed treatment can increase the damage risk of $P$. chrysocephala by making an earlier plant infestation possible. The very long period of egg laying following mild winter conditions observed in this study may be an important reason for high population densities of this pest in many oilseed rape growing regions in Europe in recent years. This is particularly the case when beetle populations cannot be controlled by insecticidal seed treatments and the alternatively applied insecticidal pyrethroid sprays show only a reduced efficacy due to build-up of pyrethroid resistance in the $P$. chrysocephala population.

Acknowledgements Thanks to all students and research assistants for their support in the field and laboratory. Thanks to UFOP (Union for promoting oil and protein plants e.V.) for financial support of the PhD project.

Author contributions All studies were carried out as part of a Ph.D. project at JKI (Institute for Plant Protection in Field Crops and Grassland, Braunschweig, Germany) in 2015-2018.

Funding Open Access funding enabled and organized by Projekt DEAL. The study was not founded by any kind of organization.

\section{Declration}

Conflict of interest There is no conflict of interest.

Open Access This article is licensed under a Creative Commons Attribution 4.0 International License, which permits use, sharing, adaptation, distribution and reproduction in any medium or format, as long as you give appropriate credit to the original author(s) and the source, provide a link to the Creative Commons licence, and indicate if changes were made. The images or other third party material in this article are included in the article's Creative Commons licence, unless indicated otherwise in a credit line to the material. If material is not included in the article's Creative Commons licence and your intended use is not permitted by statutory regulation or exceeds the permitted use, you will need to obtain permission directly from the copyright holder. To view a copy of this licence, visit http://creativecommons.org/licenses/by/4.0/.

\section{References}

Alford DV, Nilsson C, Ulber B (2003) Insect pests of winter oilseed rape crops. In: Alford DV (ed) Biocontrol of oilseed rape pests. Blackwell Science, Oxford, pp 9-41

Baroso JM (2013) Commission Implementing Regulation (EU) No 485/2013 of 24 May 2013. Official Journal of the European Union

Bergermeier A (1992) ELWIRA-Entscheidungsmodell für den Insektizideinsatz in Winterraps. Ph.d. thesis, Justus-Liebig-Universität Gießen 
Bonnemaison L, Jourdheuil P (1954) L'altise d'hiver du colza (Psylliodes chrysocephala L.). Annales Des Épiphyties 4:345-524

Brandes M, Heimbach U, Ulber B (2017) Effects of insecticide application on parasitism rates of pollen beetle larvae (Brassicogethes aeneus (Fabricius)) by tersilochine parasitoids. Arthropod Plant Interact. https://doi.org/10.1007/s11829-017-9580-y

Büchs W (1992) Insektizide gegen den Rapserdfloh einsparen. Der Pflanzenarzt 45:23-25

Conrad N (2019) Ansätze zur Verbesserung der Bekämpfung des Rapserdflohs (Psylliodes chrysocephala L.) in Winterraps (Brassica napus L.) durch gezielte Untersuchungen zur Biologie und Schadpotenzial unter besonderer Berücksichtigung von Befallszeitpunkt und-stärke. Ph.d thesis, Christian-Albrechts Universität zu Kiel

Conrad N, Brandes M, Will T, Verreet J-A, Ulber B, Heimbach U (2018) Effects of insecticidal seed treatments and foliar sprays in winter oilseed rape in autumn on insect pests and TuYV infection. J Plant Dis Prot 125:557-565

Dewar AM (2017) The adverse impact of the neonicotinoid seed treatment ban on crop protection in oilseed rape in the United Kingdom. Pest Manag Sci 73:1305-1309

Godan D (1948) Bericht über die im Winter 1947/48 durchgeführten Untersuchungen von Raps- und Rübsenproben auf Befall mit Rapserdfloh (Psylliodes chrysocephala L.)-Larven. Nachrichtenblatt Des Deutschen Pflanzenschutzdienstes 2:38-39

Godan D (1950) Über die Wirkung des Rapserdflohlarven-Befalls auf die Rapspflanze. Mitteilungen aus der Biologischen Zentralanstalt für Land- und Forstwirtschaft Berlin-Dahlem 69

Godan D (1951a) Die Miniertätigkeit der Larven des Rapserdflohes (Psylliodes chrysocephala L.). Zeitschrift Für Angewandte Entomologie 32:458-475

Godan D (1951b) Über den Einfluß hoher und tiefer Temperaturen auf die Entwicklungsstadien des Rapserdflohs (Psylliodes chrysocephala L.). Zeitschrift Für Pflanzenbau Und Pflanzenschutz 45:169-178

Green DB (2008) Revised thresholds for cabbage stem flea beetle on oilseed rape. HGCA Project report No. 428

Hausmann J, Brandes M, Heimbach U (2019) Effects of dropleg application technique during flowering of oilseed rape on insect pests. Crop Prot 126:104917

Heimbach U, Brandes M (2016) Pyrethroid resistance of insect pests in oilseed rape in Germany since 2005. IOBC-WPRS Bull 116:17-22

Højland DH, Nauen R, Foster SP, Williamson MS, Kristensen M (2015) Incidence, spread and mechanisms of pyrethroid resistance in european populations of the cabbage stem flea beetle, Psylliodes chrysocephala L. (Coleoptera Chrysomelidae). PLoS ONE 10:e0146045
Hoßfeld R (1993) Die Gelbschale als Entscheidungshilfe bei der Bekämpfung des Rapserdflohs (Psylliodes chrysocephala L.). Gesunde Pflanzen 45:291-295

Johnen A (2009) Entscheidend ist die Witterung. DLG-Mitteilungen $49-53$

Johnen A (1997) Witterungsverlauf Bestimmt Die Behandlungstermine Raps 15:56-60

Johnen A, Meier H (2000) A weather-based decision support system for managing oilseed rape pests. British Crop Prot Conf Pests Dis 2:793-800

Kaufmann O (1941) Zur Biologie des Rapserdflohs (Psylliodes chrysocephala L.). Zeitschrift für Pflanzenkrankheiten (Pflanzenpathologie) und Pflanzenschutz 51:305-324

Laird NM, Ware JH (1982) Random-effects models for longitudinal data. Biometrics 38:963-974

Mathiasen H, Bligaard J, Esbjerg P (2015a) Survival of cabbage stem flea beetle larvae, Psylliodes chrysocephala, exposed to low temperatures. Entomol Exp Appl 157:220-226

Mathiasen H, Sørensen H, Bligaard J, Esbjerg P (2015b) Effect of temperature on reproduction and embryonic development of the cabbage stem flea beetle, Psylliodes chrysocephala L., (Coleoptera. Chrysomelidae). J Appl Entomol 139:600-608

Nilsson C (2002) Strategies for the control of cabbage stem flea beetle on winter rape in Sweden. IOBC-WPRS Bull 25:133-139

Nilsson C, Büchs W, Klukowski Z, Luik A, Ulber B, Williams IH (2015) Integrated crop and pest management of winter oilseed rape (Brassica napus L.). Zemdirbyste Agric 102:325-334

Schall R (1991) Estimation in generalized linear models with random effects. Biometrika 78:719-727

Schulz RR (1983) Zur Biologie, Ökologie und Schadwirkung des Rapserdflohs (Psylliodes chrysocephala L.) an Winterraps (Brassica napus L. oleifera Metzg.). Ph.D. thesis, Wilhelm-Pieck-Universität Rostock

Schulz RR, Daebeler F (1984) Zum Schaden durch den Rapserdfloh (Psylliodes chrysocephala L.), insbesondere seiner Imagines. Nachrichtenblatt Für Den Pflanzenschutz In Der DDR 38:113-115

The R Development Core Team (2015) R: A language and environment for statistical computing. R Foundation for Statistical Computing, Vienna, Austria

Zuur AF, Ieno EN, Walker N, Saveliev AA, Smith GM (2009) Mixed effects models and extensions in ecology with R. Springer, New York

Publisher's Note Springer Nature remains neutral with regard to jurisdictional claims in published maps and institutional affiliations. 